\title{
Metabolisable energy levels for stress broilers under thermal stress
}

\author{
Níveis de energia metabolizável para frangos de corte em estresse térmico
}

\author{
MELO, Fúlvio Viegas Santos Teixeira de ${ }^{1} \mathbb{O}$; SOUZA, Antônio Ramires Lyra ${ }^{2}$; ; CRUZ \\ NETO, Manoel Adriano da ${ }^{2}{ }^{\circ}$; MENDES, Damião Bonfim ${ }^{4} \mathbb{O}^{\text {; }}$ \\ MELO, José Fernando Bibiano ${ }^{3}$
}

\begin{abstract}
${ }^{1}$ Instituto Federal de Educação Ciência e Tecnologia Baiano-IF Baiano, Rua Barão de Camaçari, 118 , Catu, Bahia, 48110-000, Brasil

${ }^{2}$ Instituto Federal de Educação Ciência e Tecnologia Baiano-IF Baiano, Km 04 da estrada do igara Senhor do Bonfim, Bahia, 58970-000, Brasil

${ }^{3}$ Universidade Federal do Vale do São Francisco-UNIVASF, Centro de Ciências Agrárias. Rodovia BR407, Km 12, Petrolina, Pernambuco, 56300-000, Brasil

${ }^{4}$ Universidade do Estado da Bahia-UNEB, Departamento de Ciências Agrárias Brasil Av. R. Edgard

Chastinet s/n, São Geraldo, Juazeiro, Bahia, 48900-000, Brasil
\end{abstract}

\section{RESUMO}

A pesquisa foi realizada com o objetivo de avaliar os diferentes níveis de energia metabolizável $(3050,3100,3150,3200$ e $3250 \mathrm{kcal} . \mathrm{kg}-1)$ na dieta de frango de corte de 22 a 42 dias de idade, mantidos em ambiente de estresse térmico. Trezentos pintos, machos com $814,7 \mathrm{~g}$ de peso médio inicial, foram distribuídos em delineamento experimental inteiramente casualizado, com cinco tratamentos, seis repetições e dez aves por unidade experimental. Os níveis de energia metabolizável das rações não influenciaram $(\mathrm{P}>0,05)$ as variáveis de desempenho conversão alimentar (CA), ganho diário de peso (GDP) e consumo diário de ração (CDR), nas duas fases estudadas, para as características de carcaça não houve diferenças estatísticas para os rendimentos de: carcaça, peito, coxa, sobrecoxa, coração, asa e dorso, sendo observadas diferenças para as variáveis, rendimento de moela e gordura abdominal. Foi observado aumento linear na porcentagem de gordura abdominal de acordo com o aumento dos níveis de energia na ração. O nível $3100 \mathrm{Kcal.kg-1}$ de energia metabolizável é o nível indicado nesta pesquisa por apresentar menor teor de gordura abdominal e menor custo por quilo de ração.
Palavras-chave: avicultura, rações energéticas, temperaturas elevadas.

\begin{abstract}
The research was carried out with the objective of evaluating different levels of metabolisable energy $(3050,3100,3150$, 3200 and $3250 \mathrm{kcal} . \mathrm{kg}-1)$ in the diet of 22to-42-day-old broilers kept in an environment of thermal stress. Three hundred male chicks weighing $814.7 \mathrm{~g}$ initial average weight were distributed in a completely randomised design with five treatments, six replications and ten birds per experimental unit. Feed metabolisable energy levels did not influence $(\mathrm{P}>0.05)$ the performance variables of feed conversion, daily weight gain and daily feed intake in the two phases studied. There were no statistical differences in carcass yields: carcass, chest, thigh, drumstick, heart, wing and back. Differences were observed for the two variables gizzard yield and abdominal fat. A linear increase in the percentage of abdominal fat with an increase in energy levels in the diet was observed. The $3100 \mathrm{kcal} . \mathrm{kg}-1$ level of metabolisable energy is the level indicated by this research because it results in lower abdominal fat content and lower cost per kilo of feed.
\end{abstract}

Keywords: elevated temperatures, energy feeds, poultry. 


\section{INTRODUCTION}

The Brazilian agricultural sector has transformed poultry farming into an industrial enterprise, as well as a great source of animal protein production. According to the Brazilian Association of Animal Protein ABPA (2018), Brazil is the second largest chicken meat producer in the world, with production of 13.06 million metric tons in 2017. Of the total volume produced, $66.9 \%$ was for domestic consumption and $33.1 \%$ for export. Of the total domestic consumption, $34.32 \%$ was slaughtered in the state of Paraná, the state that slaughtered the most (BAPA, 2018).

Broiler chickens are homeotherm animals; that is, they can maintain body temperature within a narrow range when subjected to variations in the thermal environment within a certain range. To do so, they may use behavioural adaptations such as wing spreading, spreading or nesting relative to other birds (SCHIASSI et al. 2015). According to Silva et al. (2012), the process of maintaining homeothermia is only efficient when the ambient temperature is within the limits of thermoneutrality, and birds do not adjust perfectly to temperature extremes, and may even have their lives threatened.

The high growth rate of modern broiler chickens is largely the result of genetic improvement and production conditions such as nutrition and management (RAMOS et al., 2011). Thus, knowledge of the chemical and energetic composition of the ingredients used in poultry diets is necessary for the formulation of more efficient and economical rations, since food is the most expensive item in the production of broiler chickens (CAIRES et al., 2008). Oils and fats have emerged as excellent sources of energy and essential fatty acids in poultry feed, increasing feed energy intake to compensate for low nutrient intake due to reduced consumption in warm climates and improving palatability (NOBAKHT et al., 2011).

Broiler breeders in the semi-arid regions point to difficulties in formulating feed. According to Medeiros et al. (2015) tables direct the fulfilment of the nutritional requirements for birds in temperature regions and mild environments, since these tables were developed based on data from experiments performed in these particular regions. Based on this, the nutritional requirements of the birds are modified in high-temperature situations. Thus, the objective of this research was to evaluate the performance of broiler chickens aged 22 to 42 days fed diets containing different levels of metabolisable energy in hightemperature environments.

\section{MATERIALS AND METHODS}

The experiment was conducted in the poultry sector of the Federal Institute of Education, Science and Technology of Bahia - IF Baiano - Campus Senhor do Bonfim-BA, during November and December 2017, with certificate of approval from the Commission of Ethics of Animal Use (CEUA) No. 63/2017 of the School of Veterinary Medicine and Animal Science of the Federal University of Bahia. Three hundred 22day-old Cobb broilers were used, distributed in a completely randomised experimental design, with five treatments (metabolisable energy levels: $3050, \quad 3100, \quad 3150, \quad 3200$ and $3250 \mathrm{kcal} . \mathrm{kg}-1)$ with six replications and 10 birds per experimental unit. The birds were housed on a shack in an experimental house; 30 roofed boxes of 
$1 \mathrm{~m} 2$ area were used. Into all the boxes were placed a pendular drinker and a pendular feeder. Throughout the experimental period, temperature and humidity data were collected twice a day, morning and afternoon: $30.3{ }^{\circ} \mathrm{C}$ and $49.0 \% ; 26.1{ }^{\circ} \mathrm{C}$ and $61.2 \%$, respectively, with an average daily thermal inversion of $8.3 \%$. The temperature of the experimental house remained above the thermoneutral zone throughout the study due to the climate of the region. In addition, fluorescent lamps were kept on 24 hours a day. Digital thermohygrometers distributed in the house and in the experimental cages were used to measure internal and external temperature and internal humidity. During the night the house was kept closed by (impermeable) PVC tarpaulin curtains. The experimental diets are shown in Table 1.

Table 1. Percentage composition of ingredients used in experimental diets.

\begin{tabular}{lcccccccccc}
\hline & \multicolumn{9}{c}{ Energy Levels (kcal.kg-1) } \\
\cline { 2 - 11 } & \multicolumn{9}{c}{ Growth } & \multicolumn{5}{c}{ Termination } \\
\cline { 2 - 11 } Ingredients (\%) & 3050 & 3100 & 3150 & 3200 & 3250 & 3050 & 3100 & 3150 & 3200 & 3250 \\
\hline Soybean meal & 32.8 & 33.0 & 33.24 & 33.45 & 33.67 & 28.87 & 29.08 & 29.29 & 29.50 & 29.71 \\
& 2 & 3 & & & & & & & & \\
Ground corn & 57.8 & 56.7 & 55.53 & 54.35 & 53.18 & 62.68 & 61.50 & 60.32 & 59.14 & 57.97 \\
& 9 & 1 & & & & & & & & \\
Soy oil & 3.74 & 4.71 & 5.68 & 6.65 & 7.62 & 2.92 & 3.88 & 4.85 & 5.82 & 6.79 \\
Salt & 0.08 & 0.08 & 0.08 & 0.08 & 0.08 & 0.07 & 0.07 & 0.07 & 0.07 & 0.07 \\
L-Lysine HCl 78\% & 0.25 & 0.25 & 0.24 & 0.24 & 0.24 & 0.28 & 0.28 & 0.27 & 0.27 & 0.26 \\
DL-Methionine & 0.21 & 0.21 & 0.21 & 0.21 & 0.21 & 0.19 & 0.19 & 0.19 & 0.19 & 0.19 \\
99\% & & & & & & & & & & \\
Premix Vit/Min & 5.00 & 5.00 & 5.00 & 5.00 & 5.00 & 5.00 & 5.00 & 5.00 & 5.00 & 5.00 \\
\hline Calc. Values (\%) & & & & & & & & & & \\
\hline Crude protein & 19.8 & 19.8 & 19.80 & 19.80 & 19.80 & 18.40 & 18.40 & 18.40 & 18.40 & 18.40 \\
& 0 & 0 & & & & & & & & \\
MS (kcal.kg ${ }^{-1}$ ) & 3050 & 3100 & 3150 & 3200 & 3250 & 3050 & 3100 & 3150 & 3200 & 3250 \\
Calcium & 1.02 & 1.02 & 1.02 & 1.02 & 1.02 & 1.01 & 1.01 & 1.01 & 1.01 & 1.01 \\
Match available & 0.38 & 0.38 & 0.38 & 0.38 & 0.38 & 0.38 & 0.38 & 0.38 & 0.38 & 0.38 \\
Total Methionine & 0.59 & 0.59 & 0.59 & 0.59 & 0.59 & 0.55 & 0.55 & 0.55 & 0.55 & 0.55 \\
Met. + total Cyst. & 0.91 & 0.91 & 0.91 & 0.91 & 0.91 & 0.85 & 0.85 & 0.85 & 0.85 & 0.85 \\
Total Lysine & 1.25 & 1.25 & 1.25 & 1.25 & 1.25 & 1.17 & 1.17 & 1.17 & 1.17 & 1.17 \\
Sodium & 0.20 & 0.20 & 0.20 & 0.20 & 0.20 & 0.19 & 0.19 & 0.19 & 0.19 & 0.19 \\
\hline
\end{tabular}

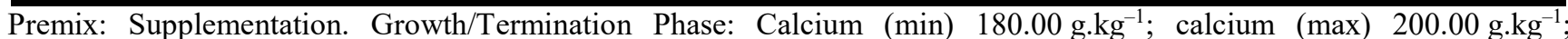
phosphorus (min) 30.00 g. $\mathrm{kg}^{-1}$; sodium (min) $3500.00 \mathrm{mg} . \mathrm{kg}^{-1}$; iron (min) $450.00 \mathrm{mg} . \mathrm{kg}^{-1}$; copper (min) $2405.00 \mathrm{mg} . \mathrm{kg}^{-1}$; zinc (min) 750.00 mg.kg ${ }^{-1}$; manganese (min) $1050.00 \mathrm{mg} . \mathrm{kg}^{-1}$; iodine (min) $15.00 \mathrm{mg} . \mathrm{kg}^{-1}$; selenium (min) $5.25 \mathrm{mg} . \mathrm{kg}^{-1}$; cobalt (min) 3.00 mg. $\mathrm{kg}^{-1}$; vitamin A (min) 200,000.00 Ul. $\mathrm{kg}^{-1}$; vitamin $\mathrm{D}_{3}$ (min) 50,000.00 Ul. $\mathrm{kg}^{-1}$; vitamin $\mathrm{E}$ (min) 350.00 Ul. $\mathrm{kg}^{-1}$; vitamin $\mathrm{K}_{3}$ (min) $40.00 \mathrm{mg} . \mathrm{kg}^{-1}$; folic acid (min) $10.00 \mathrm{mg} . \mathrm{kg}^{-1}$; biotin (min) $1.20 \mathrm{mg} . \mathrm{kg}^{-1}$; choline (min) $3500.00 \mathrm{mg} . \mathrm{kg}^{-1}$; niacin (min) $500.00 \mathrm{mg} . \mathrm{kg}^{-1}$; pantothenic acid (min) $300.00 \mathrm{mg} . \mathrm{kg}^{-1}$; vitamin $\mathrm{B}_{1}$ (min) $30.00 \mathrm{mg} . \mathrm{kg}^{-1}$; vitamin $\mathrm{B}_{2}$ (min) 150.00 mg.kg $\mathrm{kg}^{-1}$; vitamin $\mathrm{B}_{6}$ (min) $40.00 \mathrm{mg} \cdot \mathrm{kg}^{-1}$; vitamin $\mathrm{B}_{2}$ (min) $150.00 \mathrm{mg} \cdot \mathrm{kg}^{-1}$; vitamin $\mathrm{B}_{6}$ (min) 40.00 mg.kg ${ }^{-1}$; vitamin $\mathrm{B}_{12}$ (min) $300.00 \mathrm{mcg} . \mathrm{kg}^{-1}$; methionine (min) 6100.00 mg. $\mathrm{kg}^{-1}$; lysine (min) 16.00 g.kg $\mathrm{kg}^{-1}$ phytase (min) $10,000.00 \mathrm{ftu} \cdot \mathrm{kg}^{-1}$.

The research was conducted using two feeding programmes: growth (22 to 35 days) and termination (36 to 42 days). The birds were weighed at the beginning 
and end of the experiment, the feed was given ad libitum, and the dietary leftovers were collected at the end of each phase, thus obtaining data for the calculation of daily weight gain (DWG), feed conversion (FC) and daily feed intake (DFI). The animals were slaughtered at the age of 42 days. After slaughter, the birds were weighed for carcass evaluation. Carcass, chest, thigh, drumstick, liver, heart, gizzard, wing, back and abdominal fat were evaluated. The parts were weighed on a precision scale and data collected for analysis.
The results were submitted to variance analysis and when there was significant difference, regression analysis was applied using the SISVAR software. The means of the treatments were compared by Tukey test at $5 \%$.

\section{RESULTS AND DISCUSSION}

The results for DWG, DFI and FC of broilers fed with different levels of metabolisable energy in the growing phase and maintained in a thermal stress environment are given in Table 2.

Table 2. Performance of broilers fed with different levels of metabolisable energy in the growth phase (22 to 35 days) and reared in a thermal stress environment.

\begin{tabular}{lccccccc}
\hline Variables & \multicolumn{9}{c}{ Energy Levels $\left(\mathrm{kcal} . \mathrm{kg}^{-1}\right)$} & $\mathrm{R}^{2}$ & \multirow{2}{*}{ CV (\%) } \\
\cline { 2 - 5 } & 3050 & 3100 & 3150 & 3200 & 3250 & & \\
\cline { 2 - 5 } FC $\left(\mathrm{g} . \mathrm{g}^{-1}\right)$ & 2.29 & 2.27 & 2.24 & 2.20 & 2.16 & 0.99 & 5.69 \\
DWG (g) & 49.37 & 49.17 & 49.42 & 49.40 & 50.94 & 0.89 & 6.59 \\
& & & & & & & \\
DFI (g) & 169.63 & 167.27 & 165.21 & 163.04 & 165.34 & 0.91 & 4.03 \\
\hline
\end{tabular}

The DWG of the birds was not influenced $(\mathrm{P}>0.05)$ by the dietary metabolisable energy levels in the growing phase. These results are dissimilar to those reported by Barbosa et al. (2008), who used metabolisable energy levels in diets for broilers kept in a high-temperature environment (maximum average temperature of $36.6^{\circ} \mathrm{C}$ ), presenting the highest absolute weight gain of $61.72 \mathrm{~g}$ in the growth phase when a level of metabolisable energy (ME) of $3100 \mathrm{kcal} . \mathrm{kg}-1$ was used.

In the present research, no significant differences $(\mathrm{P}>0.05)$ were observed for $\mathrm{FC}$ in the growth phase. These results differ from those reported by Oliveira Neto (2000), who evaluated the effect of ambient temperature on the performance and carcass characteristics of broilers fed a controlled diet with two levels of metabolisable energy: increasing the level of ME in the diets from 3075 to $3300 \mathrm{kcal} . \mathrm{kg}-1$ resulted in improvements in FC from 2.27 to 2.25 (g.g-1). When exposed to high ambient temperatures, birds decrease food consumption substantially (BOIAGO et al., 2013). Consequently, they increase their water intake, as reported by Laganá (2008), which results in a worse FC index. The results found in this research in the growth phase agree with those of Cordeiro et al. (2010), who found the best FC value of $1.68 \mathrm{~g} . \mathrm{g}-1$ in the third week of the birds' life. These same authors state that broilers under heat stress reduce feed intake and increase 
energy expenditure for heat dissipation, resulting in high $\mathrm{FC}$ and low weight.

The DFI of the birds was not influenced $(\mathrm{P}>0.05)$ by the ME levels of the diets in the growing phase. These results corroborate those of Sakomura et al. (2004), who evaluated the effect of dietary ME level on performance and energy metabolism of broiler chickens and observed that the ME levels of the diet did not affect the DFI: $171.43 \mathrm{~g}$ for birds that consumed $3200 \mathrm{kcal} . \mathrm{kg}-1$. The stress generated by the variation in the thermal environment experienced by the animal directly influences productivity by altering the heat exchange with the environment, the amount of food consumed, the body weight gain and, consequently, the nutritional requirements (SOUZA \& BATISTA, 2012).

No significant differences $(\mathrm{P}>0.05)$ were observed between treatments in the finishing phase for broilers fed with different energy levels, as indicated in Table 3 .

Table 3. Performance of broilers fed with different levels of ME in the finishing phase (36 to 42 days) reared in a thermal stress environment.

\begin{tabular}{|c|c|c|c|c|c|c|c|}
\hline \multirow[t]{2}{*}{ Variables } & \multicolumn{5}{|c|}{ Energy levels (kcal. $\mathrm{kg}^{-1}$ ) } & \multirow[t]{2}{*}{$\mathrm{R} 2$} & \multirow{2}{*}{$\begin{array}{l}\text { CV } \\
(\%)\end{array}$} \\
\hline & 3050 & 3100 & 3150 & 3200 & 3250 & & \\
\hline $\mathrm{FC}\left(\mathrm{g} \cdot \mathrm{g}^{-1}\right)$ & 1.17 & 1.18 & 1.17 & 1.19 & 1.11 & 0.68 & 6.44 \\
\hline DWG (g) & 95.48 & 90.47 & 88.66 & 85.94 & 91.54 & 0.89 & 12.90 \\
\hline DFI $(g)$ & 111.74 & 106.92 & 103.08 & $102 ., 32$ & 102.50 & 0.99 & 13.44 \\
\hline
\end{tabular}

For DFI no statistical differences $(\mathrm{P}>0.05)$ were observed between treatments. Lima et al. (2008), in a study with different energy levels of 2900 , 3000 and $3100 \mathrm{kcal} . \mathrm{kg}-1$, lysine and methionine + cystine, in the diet for male broilers from 1 to 40 days, observed that the lowest daily intake of $100.57 \mathrm{~g}$ was obtained with the lowest energy level $(\mathrm{P}<0.05)$. For these authors, higher intake may be associated with higher oil levels in medium- and high-energy diets; this increases palatability, favouring increased feed intake. This behaviour was not confirmed by the results obtained in this study.

In the present research, no significant differences in DWG $(\mathrm{P}>0.05)$ were observed for different ME levels of the diet in the finishing phase. Similar results were found by Mendonça et al. (2008), who observed no effect of feed energy levels on DWG, evaluated in their research metabolisable energy levels for slow growing male broilers raised from 22 to 49 days of age, found values for a greater DWG in the treatment that was offered $3150 \mathrm{Kcal} . \mathrm{kg}-1$ of MS obtained $36.21 \mathrm{~g}$, although the lowest value found in absolute weight was $34.39 \mathrm{~g}$ for the $2700 \mathrm{Kcal}$ treatment. $\mathrm{kg}-1$. The nonsignificance in the results of this research can be justified by the fact that the ambient temperature is determinant in the performance of broilers, a physical factor that has a great influence on the 
amount of food consumed by the birds, directly compromising the weight gain. According to Nazareno et al. (2009), the thermoneutrality zone is related to an ideal thermal environment, in which birds experience suitable conditions to express their best productive characteristics.

No significant differences $(\mathrm{P}>0.05)$ were observed in $\mathrm{FC}$ in the termination phase with the ME levels of the diet. These results confirm those obtained by Roll et al. (2011), who also found no effect of energy levels on FC, obtaining a better value of $2.44 \mathrm{~g} . \mathrm{g}-1$ for this variable when a diet of ME level 3050 kcal.kg-1 was offered between 43 and 48 days of age. According to Olanrewaju et al. (2010), processes such as panting and wing opening to dissipate heat require extra energy expenditure. Therefore, at high temperatures there is a reduction in food utilisation efficiency, resulting in a generally higher $\mathrm{FC}$ rate.

In this study, the average temperature was $30.3{ }^{\circ} \mathrm{C}$ during the growth phase and $26.1{ }^{\circ} \mathrm{C}$ during the termination phase, characterised as outside the thermal comfort zone in both phases. According to Tinôco (1998), an environment considered comfortable is $16-23{ }^{\circ} \mathrm{C}$. Thus, these average temperature values during the research may have needed greater heat dissipation by the birds to remain in thermal equilibrium. For Beterchini et al. (1991), better results are obtained in broilers in the final phase in an environment with an average temperature of $22{ }^{\circ} \mathrm{C}$, with no significant differences seen between 17.1 and 27.9 ${ }^{\circ} \mathrm{C}$. The relative humidity of the air during the growth and termination phase was $49.0 \%$ and $61.2 \%$, respectively. According to Naas (1995), the appropriate relative humidity range for broiler chickens in their fifth week should remain in the range of $50-70 \%$. The author reported that very high temperatures associated with high relative humidity values cause a reduction in productive performance and economic losses, especially in the final stages when chickens are nearing the age for commercialisation.

For carcass yield, the variables abdominal fat and gizzard yield were significantly different $(\mathrm{P}<0.05)$ between treatments, as shown in Table 4. 
Table 4. Carcass characteristics of broilers fed diets of different levels of ME reared in a thermal stress environment.

\begin{tabular}{|c|c|c|c|c|c|c|c|c|}
\hline \multirow[t]{2}{*}{ Variables } & \multicolumn{5}{|c|}{ Energy levels (kcal kg-1) } & \multirow[t]{2}{*}{$\mathrm{R}^{2}$} & \multirow[t]{2}{*}{ Equation } & \multirow[t]{2}{*}{$\mathrm{CV}(\%)$} \\
\hline & $\begin{array}{c}305 \\
0\end{array}$ & 3100 & 3150 & 3200 & 3250 & & & \\
\hline $\begin{array}{l}\text { Y. carcass. } \\
(\%)\end{array}$ & $\begin{array}{l}77 . \\
09\end{array}$ & $\begin{array}{c}75.6 \\
7\end{array}$ & 73.00 & 73.58 & 80.31 & 0.84 & - & 11.91 \\
\hline $\begin{array}{l}\text { Y. chest } \\
(\%)\end{array}$ & $\begin{array}{l}24 . \\
96\end{array}$ & $\begin{array}{c}26.0 \\
0\end{array}$ & 23.70 & 26.23 & 26.75 & 0.88 & - & 11.12 \\
\hline $\begin{array}{l}\text { Y. thigh } \\
(\%)\end{array}$ & $\begin{array}{l}10 . \\
74\end{array}$ & $\begin{array}{c}11.1 \\
9\end{array}$ & 10.89 & 10.50 & 10.48 & 0.67 & - & 12.12 \\
\hline $\begin{array}{l}\text { Y. } \\
\text { drumstick } \\
(\%)\end{array}$ & $\begin{array}{c}5.8 \\
1\end{array}$ & 5.71 & 5.76 & 6.11 & 5.85 & 0.22 & - & 18.81 \\
\hline Y. liver $(\%)$ & $\begin{array}{c}1.8 \\
1\end{array}$ & 2.12 & 2.10 & 2.31 & 2.58 & 0.92 & - & 17.83 \\
\hline $\begin{array}{l}\text { Y. heart } \\
(\%)\end{array}$ & $\begin{array}{c}0.5 \\
7\end{array}$ & 0.70 & 0.68 & 0.65 & 0.72 & 0.51 & - & 26.46 \\
\hline $\begin{array}{l}\text { Y. gizzard } \\
(\%)\end{array}$ & $\begin{array}{l}0.9 \\
7 b\end{array}$ & $\begin{array}{c}1.54 \\
\mathrm{a}\end{array}$ & $1.36 \mathrm{ab}$ & $\begin{array}{c}1.36 \mathrm{a} \\
\mathrm{b}\end{array}$ & $\begin{array}{c}1.27 \mathrm{a} \\
\mathrm{b}\end{array}$ & 0.63 & $\begin{array}{c}y=- \\
0.000032942 x \\
2+ \\
0.208339879 x \\
- \\
327.93964049 \\
8\end{array}$ & 13.33 \\
\hline $\begin{array}{l}\text { Y. wing } \\
(\%)\end{array}$ & $\begin{array}{c}3.7 \\
9\end{array}$ & 4.04 & 3.83 & 3.96 & 3.60 & 0.66 & - & 8.08 \\
\hline Y. back $(\%)$ & $\begin{array}{l}14 . \\
83\end{array}$ & $\begin{array}{c}16.5 \\
8\end{array}$ & 16.01 & 16.98 & 17.12 & 0.77 & - & 14.75 \\
\hline $\begin{array}{l}\text { Abd. fat. } \\
(\%)\end{array}$ & $\begin{array}{l}2.6 \\
4 b\end{array}$ & $\begin{array}{c}3.51 \\
\mathrm{ab}\end{array}$ & $3.57 \mathrm{ab}$ & $\begin{array}{c}3.23 \mathrm{a} \\
\mathrm{b}\end{array}$ & $4.28 \mathrm{a}$ & 0.64 & $\begin{array}{c}y= \\
0.006032148 x \\
- \\
15.551953554\end{array}$ & 22.00 \\
\hline
\end{tabular}

Different letters on the same line indicate statistical difference by the F-test at $5 \%$ probability. Y. carcass. $=$ Carcass yield; Abd. fat. $=$ Abdominal fat

In this research no significant differences $(\mathrm{P}>0.05)$ were observed in carcass yield for the different ME levels of the diet; the highest relative weight of $80.31 \%$ was seen in the treatment with $3250 \mathrm{kcal} . \mathrm{kg}-$ 1 ME. Similar results were observed by Meza et al. (2015), who used ME and digestible lysine levels for broiler composition and carcass yield and did not notice significant differences on carcass yield, obtaining the highest relative weight of $73.20 \%$ when offering a diet of $3360 \mathrm{kcal} . \mathrm{kg}-1 \mathrm{ME}$. According to Baracho et al. (2013), it is known that 
animals reach their optimum productivity when kept in a thermoneutral environment; that is, when food energy is not diverted to compensate for deviations from the thermoneutral range by eliminating or maintaining heat.

Significant differences $(\mathrm{P}<0.05)$ were found for the variable abdominal fat, and it is possible to observe a simple linear effect in the regression analysis. The best index for this variable is for the $3050 \mathrm{kcal} . \mathrm{kg}-1 \mathrm{ME}$ diet and the worst for $3250 \mathrm{kcal} . \mathrm{kg}-1$ according to the equation $\mathrm{y}=0.006032148 \mathrm{x}-15.551953554$; obtaining $2.84 \%$ abdominal fat for treatment with 3050 kcal.kg-1; see Fig. 1.

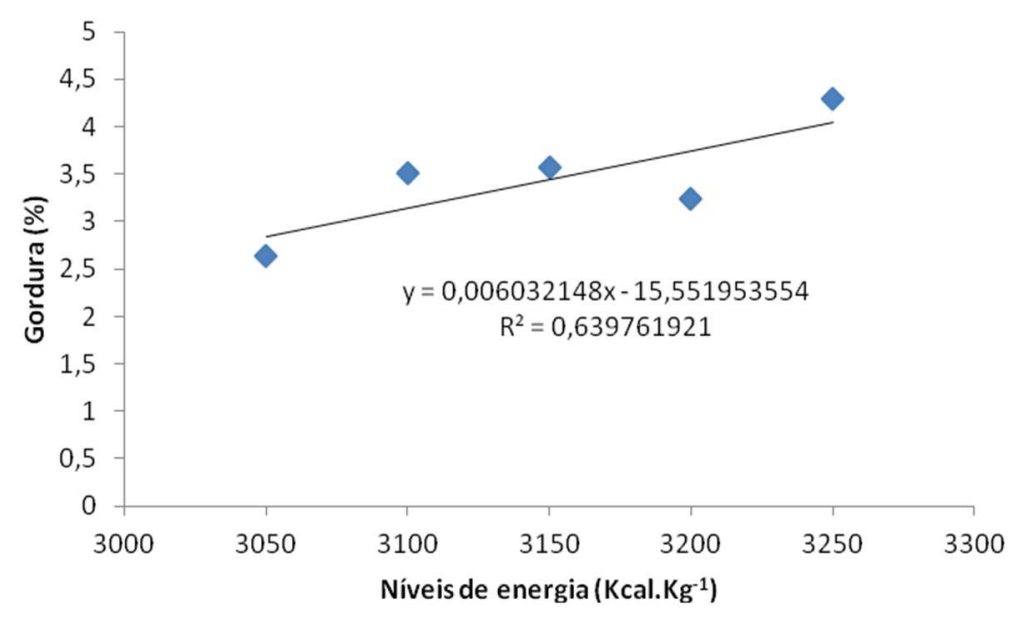

Figure 1. Abdominal fat in 42-day-old chickens fed diets containing different levels of heat stress ME.

Birds showed increased abdominal fat deposition when higher energy levels were provided in the diet, with the largest deposition of $4.05 \%$ at $3250 \mathrm{kcal} . \mathrm{kg}-1$ ME. This disagrees with the findings of Duarte et al. (2012), who evaluated the performance and duodenal morphometry of broiler chickens submitted to different energy levels and feeding programmes from 42 to 57 days old, in which the birds' abdominal fat percentage was not affected $(\mathrm{P}>0.05)$ by the energy levels of the ration, levels of 3200 and $3600 \mathrm{kcal} . \mathrm{kg}-1$ obtaining values of $2.00 \%$ and $2.14 \%$, respectively. According to Oliveira Neto et al. (2000) this may be associated with the reduced size of metabolically active organs and protein deposition in the breast observed in birds maintained at $32{ }^{\circ} \mathrm{C}$ which provided greater amount of energy for deposition as fat in the heat environment. In addition, if the source of fat used to formulate the diet is rich in polyunsaturated fatty acids, such as soybean oil, this contributes to a greater accumulation of abdominal fat (LOPES et al. 2015).

For the variable gizzard yield, the different energy levels exerted an influence $(\mathrm{P}<0.05)$. In this research the highest gizzard yield was in the treatment with $3100 \mathrm{kcal} . \mathrm{kg}-1 \mathrm{ME}$, obtaining $1.54 \%$ relative weight and the 
lowest gizzard yield with 3050 kcal.kg$1 \mathrm{ME}$, with a value of 0.95 relative weight. A quadratic effect was observed in the applied regression analysis; according to the equation $\mathrm{y}=-$ $0.000032942 \mathrm{x} 2+0.208339879 \mathrm{x}-$ 327.939640498 it can be observed that the ideal level is $3162.2 \mathrm{kcal} . \mathrm{kg}-1 \mathrm{ME}$, yielding $1.46 \%$ - see Fig. 2. In contrast, these results do not corroborate those found by Barbosa et al. (2008), who reported that ME levels did not influence the gizzard performance of birds, evaluating effects of ME levels of 2800 , $2900,3000,3100$ and $3200 \mathrm{kcal} . \mathrm{kg}-1$ in the final phase 22 - 49 days), obtaining the highest relative gizzard weight of $2.95 \%$ with $3200 \mathrm{kcal} . \mathrm{kg}-1$ treatment at 49 days of age, and kept in a hightemperature environment. This value, which is $2.95 \%$ higher than the value found in this research, can be justified by the 7 days longer that this experiment was conducted, which, in the case of broilers, may be the number of days required for several physiological changes to occur in birds. The values found in this research for the variable gizzard yield (Fig. 2), corroborate those found by Oliveira Neto et al. (2000), who obtained a relative weight of $1.59 \%$ when using a diet of ME level 3075 kcal.kg-1, evaluating the effect of room temperature on the performance and carcass characteristics of two-diet controlled broiler chickens. These authors reported that the observed reduction in the weight of the organs of birds exposed to high ambient temperatures is a physiological adjustment to reduce body heat production.

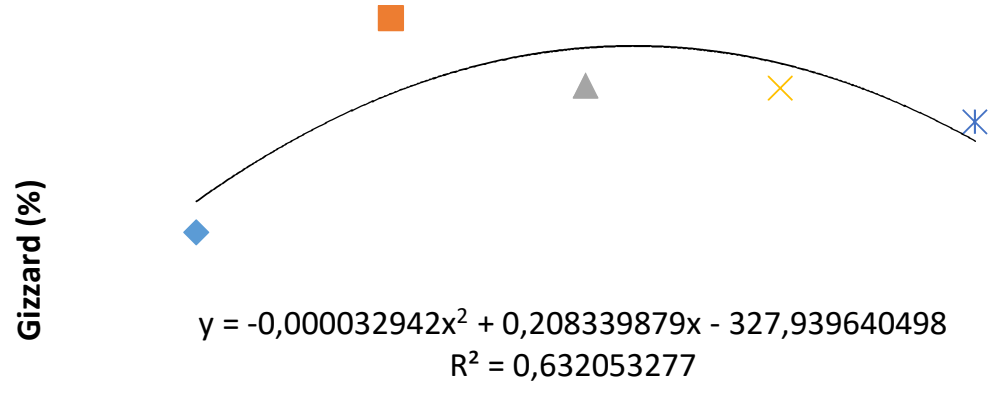

Energy level (Kcal Kg-1)

Figure 2. Gizzard yield of broilers aged 22 to 42 days fed diets containing different levels of ME under thermal stress.

Taking into account the differential of feed cost reduction, as indicated in Table 5 , it is noted that the feed with the highest cost in each phase (growth and termination) was found for treatment with $3250 \mathrm{kcal} . \mathrm{kg}-1$ of , obtaining values of $\mathrm{R} \$ \mathrm{~kg}-1 \quad 1.96$ and 1.92 , respectively. However, the lowest costs 
( $\mathrm{R} \$ \mathrm{Kg}-11.86$ and 1.82 , respectively) were offered by the rations with a level of $3050 \mathrm{kcal} . \mathrm{kg}-1 \mathrm{ME}$.

Table 5. Economic viability of broiler diets fed different $\mathrm{ME}$ levels in thermal stress environments.

\begin{tabular}{|c|c|c|c|c|c|c|c|c|c|c|}
\hline \multirow[b]{3}{*}{ Ingredients } & \multicolumn{10}{|c|}{ Energy levels (kcal. $\mathrm{kg}^{-1}$ ) } \\
\hline & \multicolumn{5}{|c|}{ Growth } & \multicolumn{5}{|c|}{ Termination } \\
\hline & 3050 & 3100 & 3150 & 3200 & 3250 & 3050 & 3100 & 3150 & 3200 & 3250 \\
\hline Soybean meal & $\begin{array}{c}32.8 \\
2\end{array}$ & $\begin{array}{c}33.0 \\
3\end{array}$ & $\begin{array}{c}33.2 \\
4\end{array}$ & 33.45 & 33.67 & 28.87 & 29.08 & 29.29 & 29.50 & 29.71 \\
\hline Ground corn & $\begin{array}{c}57.8 \\
9\end{array}$ & $\begin{array}{c}56.7 \\
1\end{array}$ & $\begin{array}{c}55.5 \\
3\end{array}$ & 54.35 & 53.18 & 62.68 & 61.50 & 60.32 & 59.14 & 57.97 \\
\hline Soy oil & 3.74 & 4.71 & 5.68 & 6.65 & 7.62 & 2.92 & 3.88 & 4.85 & 5.82 & 6.79 \\
\hline Salt & 0.08 & 0.08 & 0.08 & 0.08 & 0.08 & 0.07 & 0.07 & 0.07 & 0.07 & 0.07 \\
\hline $\begin{array}{l}\text { L-Lysine } \mathrm{HCl} \\
78 \%\end{array}$ & 0.25 & 0.25 & 0.24 & 0.24 & 0.24 & 0.28 & 0.28 & 0.27 & 0.27 & 0.26 \\
\hline $\begin{array}{l}\text { DL-Methionine } \\
99 \%\end{array}$ & 0.21 & 0.21 & 0.21 & 0.21 & 0.21 & 0.19 & 0.19 & 0.19 & 0.19 & 0.19 \\
\hline Premix Vit/Min & 5.00 & 5.00 & 5.00 & 5.00 & 5.00 & 5.00 & 5.00 & 5.00 & 5.00 & 5.00 \\
\hline \multicolumn{11}{|l|}{$\begin{array}{l}\text { Calculated value } \\
\left(\mathrm{R} \$ \mathrm{~kg}^{-1}\right)\end{array}$} \\
\hline $\begin{array}{l}\text { Soybean Bran } \\
(1.03)\end{array}$ & $\begin{array}{c}33.8 \\
0\end{array}$ & $\begin{array}{c}34.0 \\
2\end{array}$ & $\begin{array}{c}34.2 \\
3\end{array}$ & 34.45 & 34.66 & 29.72 & 29.95 & 30.16 & 30.38 & 30.60 \\
\hline $\begin{array}{l}\text { Ground Corn } \\
(0.55)\end{array}$ & $\begin{array}{c}31.8 \\
3\end{array}$ & $\begin{array}{c}31.1 \\
9\end{array}$ & $\begin{array}{c}30.5 \\
4\end{array}$ & 29.89 & 29.24 & 34.46 & 33.81 & 33.17 & 32.52 & 31.87 \\
\hline $\begin{array}{l}\text { Soybean Oil } \\
(3.49)\end{array}$ & $\begin{array}{c}13.0 \\
5\end{array}$ & $\begin{array}{c}16.4 \\
3\end{array}$ & $\begin{array}{c}19.8 \\
2\end{array}$ & 23.20 & 26.55 & 10.15 & 13.54 & 16.92 & 20.31 & 23.69 \\
\hline Salt (0.90) & 0.07 & 0.07 & 0.07 & 0.07 & 0.07 & 0.05 & 0.05 & 0.05 & 0.05 & 0.06 \\
\hline L-Lysine $\mathrm{HCl}$ & 45.0 & 44.8 & 43.1 & 43.37 & 42.66 & 50.58 & 49.86 & 49.14 & 48.42 & 47.52 \\
\hline $78 \%(7.20)$ & 0 & 2 & 9 & & & & & & & \\
\hline DL-Met. 99\% & 42.1 & 42.4 & 42.6 & 42.80 & 43.00 & 37.60 & 37.80 & 38.00 & 38.40 & 38.60 \\
\hline$(8.00)$ & 9 & 0 & 0 & & & & & & & \\
\hline $\begin{array}{l}\text { Prém Vit/Min } \\
(4.04)\end{array}$ & $\begin{array}{c}20.2 \\
0\end{array}$ & $\begin{array}{c}20.2 \\
0\end{array}$ & $\begin{array}{c}20.2 \\
0\end{array}$ & 20.20 & 20.20 & 20.20 & 20.20 & 20.20 & 20.20 & 20.20 \\
\hline Total value for & 186. & 189. & 190. & 193.98 & 196.3 & 182.7 & 185.2 & 187.6 & 190.2 & 192.5 \\
\hline $100 \mathrm{~kg}$ & 14 & 13 & 65 & & 8 & 6 & 1 & 4 & 8 & 4 \\
\hline
\end{tabular}

Sources - Soy: City/Barreiras/BA (R\$62.00/60 kg) https://www.agrolink.com.br/cotacoes/graos/soja/sojaem-grao-sc-60 kg; Dried corn: City/ Barreiras/BA (R $\$ 33.50 / 60 \mathrm{~kg})$ https://www.agrolink.com.br/cotacoes/graos/milho/milho-seco-sc-60 kg; Soy oil: City/SãoPaulo/SP (900mlcom20uni./R \$64.95) http://www.atacadouniao.com.br/oleo-de-soja-vila-velha-20x900ml-.html; Salt: City/SãoPaulo/SP (R $\$ 12 / 25 \mathrm{~kg}) \quad<$ http://www.mfrural.com.br/detail/sal-refined-scs-25 kg143741.aspx $>\quad$ Prix. (R $\$ 101.00 / 25 \mathrm{~kg}) \quad$ https://www.casabrasil.agr.br; DL-Methionine 99\%: $(\mathrm{R} \$ 180.00 / 25 \mathrm{~kg}) ; \quad$ and L-Lysine HCL $78 \%$ : $(\mathrm{R} \$ 200.00 / 25 \mathrm{~kg}) \quad<$ https://www.foursquare.com/v/finnofarma-farmacia-de-manipula $>$. 


\section{CONCLUSION}

Broiler feed can be formulated with metabolisable energy levels of up to $3250 \mathrm{kcal} . \mathrm{kg}-1$ without causing damage to poultry performance. According to the results obtained I indicate the level at $3100 \mathrm{kcal} . \mathrm{kg}-1$, based on feed cost data and carcass evaluation.

\section{REFERENCES}

\section{ABPA - Associação Brasileira de Proteína Animal. Relatório Anual 2016. Disponível em: <http://abpa- br.com.br/storage/files/relatorio-anual- 2018.pdf $>$ Acessado em: 30 de agosto de 2019.}

BARACHO, M.S.; CASSIANO, J. A.; NÄÄS, I. A. Ambiente interno em galpões de frango de corte com cama nova e reutilizada. Revista Agrarian Dourados, v.6, n.22, p.473-478, 2013.

BARBOSA, F.J.V.; LOPES, J.B.; FIGUEIREDO, A.V. Níveis de energia metabolizável em rações para frangos de corte mantidos em ambiente de alta temperatura. Revista Brasileira de Zootecnia, v.37, n.5, p.849-855, 2008.

BETERCHINI, A.G.; ROSTAGNO, H.S.; SILVA, M.A.; OLIVEIRA, A. Efeitos da temperatura ambiente e do nível de energia da ração sobre o desempenho e a carcaça de frangos de corte. Revista Sociedade Brasileira de Zootecnia, v. 20, n. 3, p. 218-228, 1991.

BOIAGO, M.M.; BORBA, H.; SOUZA, P.A. Desempenho de frangos de corte alimentados com dietas contendo diferentes fontes de selênio, zinco e manganês, criados sob condições de estresse térmico. Arquivo Brasileiro de Medicina Veterinária e Zootecnia, v. 65, n. 1, p. 241-247, 2013.

CAIRES, C.M.; FAGUNDES, N.S.; FERNANDES, E. A.; CARVALHO, A. $P$. Enzimas na alimentação de frangos de corte. Revista Eletrônica

Nutritime, v. 5, n. 1, p. 491-497, 2008.

CORDEIRO, M.B.; TINÔCO, I.F.F.; SILVA, J.N. Conforto térmico e desempenho de pintos de corte submetidos a diferentes sistemas de aquecimento no período de inverno. Revista Brasileira de Zootecnia, v. 39, n. 1, p. 217-224, 2010.

DUARTE, K.F.; JUNQUEIRA, O.M.; BORGES, L.L. Desempenho e morfologia duodenal de frangos de corte submetidos a diferentes níveis de energia e programas de alimentação de 42 a 57 dias de idade. Ciência Animal Brasileira, v. 13, n. 2, p. 197-204, 2012.

LANGANÁ, C. Influência de altas temperaturas na alimentação de frangos de corte. Pesquisa \& Tecnologia, v. 5, n.2, 2008.

LIMA, L.M.B.; LARA, L.J.; BAIAO, N.C. Efeitos dos níveis de energia, lisina e metionina + cistina sobre o desempenho e rendimento de frangos de corte. Revista Brasileira de Zootecnia, Viçosa, v. 37, n. 8, p. 1424-1432, 2008.

LOPES, J.C.O.; RIBEIRO, M.N.; LIMA, V.B. de. S. Estresse por calor em frangos de corte Avicultura, desempenho, infraestrutura, nutrição, temperatura. Revista Eletrônica Nutritime, v.12, n. 6, p. 4478-4487, 2015. 
MEDEIROS, T.T.B; BRANDÃO, P.A; SILVA, J.J. Desempenho produtivo de frangos de corte na fase inicial, criados no semiárido paraibano e submetidos a diferentes níveis de proteína e energia na dieta. In: X CONGRESSO NORDESTINO DE PRODUÇÃO ANIMAL, 10, 2015, Teresina. Anais... Teresina, PI: Sociedade Nordestina de Produção Animal, 2015. p.2.

MENDONÇA, M.O.; SAKOMURA, N.K.; SANTOS, F.R. Níveis de energia metabolizável para machos de corte de crescimento lento criados em semiconfinamento. Revista Brasileira de Zootecnia, v. 37, n. 8, p. 1433-1440, 2008 .

MEZA, S.K.L.; NUNES, R.V.; TSUTSUMI, C.Y. Níveis de energia metabolizável e lisina digestível sobre a composição e rendimento de carcaça de frangos de corte. Semina: Ciências Agrárias, v. 36, n. 2, p. 1079-1090. 2015.

NAAS, I, A. O equilíbrio térmico das aves: aspectos físicos. In: SIMPOSIO INTERNACIONAL SOBRE AMBIÊNCIA E INSTALAÇÕES NA AVICULTURA INDUSTRIAL, v.1, 1995, Campinas. Anais... Campinas-SP: FACTA; 1995. p. 19-23,1995.

NAZARENO, A. C.; PANDORFI, H.; ALMEIDA, G. L. P. Avaliação do conforto térmico e desempenho de frangos de corte sob regime de criação diferenciado. Revista Brasileira de Engenharia Agrícola Ambiental, v.13, p.802-808, 2009.

NOBAKHT, A.; TABATBAEI, S.; KHODAEI, S. Effects of Different Sources and Levels of Vegetable Oils on Performance, Carcass Traits and
Accumulation of Vitamin E in Breast Meat of Broilers. Journal of Biological Sciences, v. 3, n. 6, p. 601-605, 2011.

OLANREWAJU, H.A.; PURSWELL, J.L.; COLLIER AND, S.D.; BRANTON, S.L. Effect of ambient temperature and light intensity on growth performance and carcass characteristics of heavy broiler chickens at 56 days of age. International Journal of Poultry Science, v. 9, n. 8, p. 720$725,2010$.

OLIVEIRA NETO, A.R.; OLIVEIRA, R.F.M.; DONZELE, J.L. Efeito da temperatura ambiente sobre $o$ desempenho e características de carcaça de frangos de corte alimentados com dieta controlada e dois níveis de energia metabolizável. Revista Brasileira de Zootecnia, v.29, n.1, p. 183-190, 2000.

RAMOS, K. C.B.T.; GOMES, A.V. da C.; LIMA, C.A.R. de. CAMARGO, A.M.; CURVELLO, F.A.; SILVA, R.V.M.M.; MASSI, P. de. A. Desempenho produtivo e econômico de frangos de corte submetidos a programas de restrição alimentar. Ciência Animal Brasileira, v. 12, n. 1, p. 8-16, 2011.

ROLL, A.P.; LOPES, D.C.N.; AZAMBUJA, S. Efeito de diferentes níveis de energia da dieta no desempenho de frangos de corte entre os 43 e 48 dias de idade. Revista Portuguesa de Ciências Veterinárias, v. 106 (577-580) p. 69-74, 2011.

SAKOMURA, N.K.; LONGO F.A.; RABELLO, C.B. Efeito do nível de energia metabolizável da dieta no desempenho e metabolismo energético de frangos de corte. Revista Brasileira 
de Zootecnia, v. 33, n. 6, p. 1758-1767, 2004.

SCHIASSI, L.; JUNIOR, T.Y.;

FERRAZ, P.F.P. Comportamento de

frangos de corte submetidos a diferentes ambientes térmicos. Revista

Engenharia Agrícola, v. 35, n. 3, p.390-396, 2015.

SILVA, J.H.V.; FILHO, J. J.; COSTA, F.G.P. Exigências nutricionais de codornas. Revista Brasileira de Saúde e Produção Animal, v.13, n.3, p.775790, 2012.

SOUZA, B.B.; BATISTA, N.L. Os efeitos do estresse térmico sobre a fisiologia animal. Revista

Agropecuária Cientifica do

Semiárido, v. 8, n. 3, p. 06-10, 2012.

TINÔCO, I.F.F. Ambiência e

instalações para a avicultura industrial.

In: ENCONTRO NACIONAL DE TÉCNICOS, PESQUISADORES E EDUCADORES DE

CONSTRUÇÕES RURAIS, [s. n], 1995, Poços de Caldas. Anais... Poços de Caldas. MG: Sociedade Brasileira de Engenharia Agrícola, 1998. p.1-86. 